\title{
TYPES OF FOLIAR DICHOTOMY IN LIVING FERNS ${ }^{\prime}$
}

\author{
Warren H. Wagner, Jr.
}

LEAves of CERTAIN ferns are commonly cited as "primitive" on the general theory that they have retained dichotomy of the major vascular axes of the leaf from ancient psilophyte ancestors (Zimmermann, in Verdoorn, 1938; Lam, 1948). The present study suggests a re-interpretation to be based on comparisons with ordinary fern leaves, "pinnate" in the arrangement of their main veins. The term "foliar dichotomy" will be used here to refer not only to dichotomously lobed or divided leaves, but also to those with blades that are simple or nearly so, in which dichotomous organization is indicated by over-all vein pattern. The term is thus used for the basic patterns of major veins or vascular strands, without particular reference to degrees of laminar dissection, which is known to be highly variable among closely related ferns.

Fern leaves with dichotomous vascular architec. ture fall into four distinctive categories which have not previously been clearly distinguished. Each category has been named for the feature of the leaf which accounts for its peculiar organization. These categories are named as follows: (A) leaves with midribless blades-"Midribless-blade Type," (B) leaves in which the morphological blade midrib has become displaced-"Displaced-midrib Type," (C) leaves with crested blades-"Crested-blade Type," and (D) leaves with non-dichotomous blades, in which the petioles are once or repeatedly branched - "Forked-petiole Type." Each type will be discussed and the known examples of each listed.

A. MIDRIBLESS-BLADE TYPE.-The foliar dichotomy of midribless leaves is the commonest type, with the following peculiarities: (1) forking of the main veins of the blade is regular and symmetrical, (2) the basal pinnae or segments, or veins representing them, are formed, but the central portion and the midrib of the blade are absent or fail to form," and (3) blades of this type are horizontally

I Received for publication February 20, 1952.

This study was made at Harvard University during the tenure of a Gray Herbarium Fellowship. I am especially indebted for help to Professors I. W. Bailey, R. H. Wetmore, and E. B. Copeland; and for materials to Alma G. Stokey, Lenette Rogers Atkinson, Harold St. John, Edith Scamman, and Eugene Horner. Publication of this paper was aided by a grant from the Executive Board of the Horace H. Rack. ham School of Graduate Studies, University of Michigan.

2 Failure of centers of leaf-blades or their parts to develop is well known in the "dichotomy" of adult gleicheniaceous leaves. Since these retain obvious vestiges of the central axes between each pair of lateral segments, I do not include this as a type of foliar dichotomy. Attention must be called, however, to at least one species (fig. 1 ) in which the tiny "buds" located between the shanks of apparent dichotomies have disappeared. Juvenile leaves in Gleicheniaceae have been described before, and I have confirmed the changes of successive leaves in Dicranopteris emarginata and Sticherus bifidus; their first leaves are pinnate in vascular pattern oriented, and more or less cup-form. Species possessing midribless adult blades are few (only 13 known species), but most ferns have juvenile leaves of this type, exceptions being the Ophioglossaceae. certain Marattiaceae. the Gleicheniaceae, and the genus Nephrolepis (Davalliaceae) which have mid. ribbed juvenile leaf-blades.

The pinnae or what appear to be their homo. logues in midribless juvenile fronds may be entirely separate or they may be fused, and gradations occur. The youngest fronds in a series have very rudimentary venation, but in many ferns the succeeding juvenile fronds develop pinnae (or veins corresponding to them) which are identical in vein pattern with those of the later, midribbed leaves. Early fronds of closely related ferns may be quite different from each other in the amount of dissection of the blade: the two pinnae of the midribless early blades are separate in Osmunda cinnamomea (fg. 7A) and Pellaea viridis (fig. 2). but the two "pinnae" (i.e., their homologues) are mostly or entirely fused in Osmunda regalis and Pellaea atropurpurea. In certain species of Dryopteris (Aspidiaceae) and Asplenium (Aspleniaceae, example in fig. $8 \mathrm{C}$ ), the transition from midribless to midribbed blade occurs in such simple fronds that the presumed homology of the lateral lobes to hasal pinnae is not evident. In others, the transition occurs at an even earlier stage; in Polypodiaceae (sensu strictu) the blades pass directly from the stage of two lateral veinlets to that of two lateral and one central veinlet, and in Vittariaceae (fig.. 11 )

and cutting, although very small. In successive leaves. how ever, the basal pair of pinnae becomes exaggerated, and finally the central part of the leaf is reduced to a dormant or vestigial apex. In successively older leaves, pinnae themselves repeat the forking, and indeterminate, dichotomous growth results. It is desirable that juvenile leaves of the "truly dichotomous" fern illustrated be examined to determine at what stage of successive juvenile leaves the apices become suppressed to the extent of not appearing at all.

Brief mention should be made here of the complicated climbing leaves of Lygodium rircinatum (Schizaeacear) which will be reported in detail in the future. Its small leaves are "ground fronds" (i.e., they do not climb) and they are dichotomons, with two pinnae. In a series of progressively more complicated leaves, the smaller ones have two broad, horizontally oriented pinnae, which are joined in a dichotomy at the top of the petiole. But in the larger "ground fronds" (as shown by plants growing in the greenhouse of the Biological Laboratories, Harvard University). a small papilla is seen between the two pinnae, surmounting the petiole. In subsequent leaves, this papilla does not become quiescent but grows out to form a long. indeterminate, twining rachis, with pinnae that are similar to whole blades of large "ground fronds" in being represented only by their two basal pinnules, their central portions aborting. By cutting off the apex of a growing rachis, however, the author has forced the middle purtions of the pinnae to grow out. The small "ground fronds" of Lygodium represent the midribless-blade type of dichotomy. 


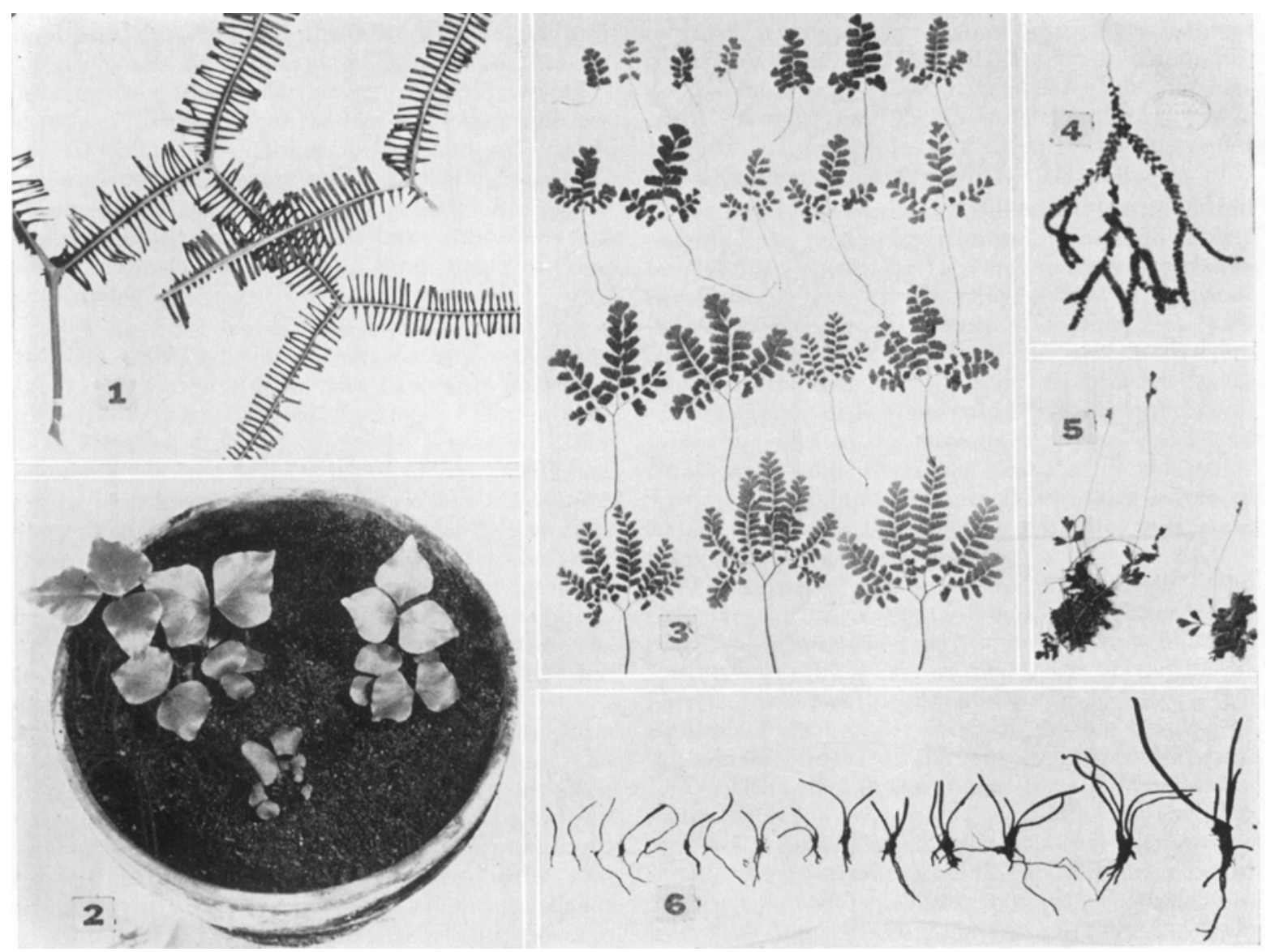

Fig. 1-6.--Fig. 1. Gleichenia (Sticherus) flagellaris var. bracteata, Malayan Peninsula (Gray Herbarium).-Fig. 2. Pellaea viridis, juvenile plants.-Fig. 3. Adiantum pedatım, juvenile leaves, Massachusetts.-Fig. 4. Ctenopteris heteromorpha, Ecuador, Fraser (Gray H.).-Fig. 5. Coptophyllum wrightii, Bahamas, Small \& Carter (Gray H.).-Fig. 6. Schizaea robusta, juvenile plants, Hawaii, St. John.

to a state of loop formation. Orth $(1938$, p. 6$)$ discusses the progressive leaves of a number of species. All his figures, however, show individual, selected stages. A large series of fronds from many rhizomes is required to illustrate successive changes, since in a sequence of leaves from one rhizome not all the intermediate conditions are represented. If a mass collection of juvenile leaves is arranged according to increasing complexity, it is noteworthy that the transition between the midribless and midribbed condition occurs abruptly, intermediates being extremely rare. In Osmunda cinnamomea and $O$. regalis, for instance, the basal pinnae (fused in $O$. regalis) have the same morphology whether the midrib forms or not, so that fronds of a large series of several hundred divide sharply into two classes, those with a "middle pinna" or "middle lobe" and those without. Special search where young sporophytes occur, however, reveals a few fronds which have a pointed "papilla" between the two side pinnae (fig. 7A). Also the "middle pinna" is sometimes much smaller than the laterals. Therefore, it may be concluded that the change from midribless to midribbed states is not entirely an "all or none" phenomenon: intermediate conditions, i.e., with "papillae," are occasionally found, the "papillae" presumably analogous to the abortive apices of leaves in the Gleicheniaceae. Intermediates have been found so far in one form or other only in Todea barbara, Osmunda regalis, O. cinnamomea (of the Osmundaceae), Pteris tremula (fig. 7C), Adiantum hispidulum, and Pellaea viridis (Pteridaceae), Asplenium trichomanes (fig. 7B, Aspleniaceae), Athyrium filix-foemina (fig. 7D) and Dryopteris campyloptera (Aspidiaceae), but when long series of other species are available, more examples may be expected.

Ideal species for study of changes in successive leaves are those with relatively large and complex early leaves possessing numerous veins, such as Diellia erecta (Aspleniaceae), Pellaea rotundifolia (Pteridaceae), Anemia phyllitidis (Schizaeaceae), Cyrtomium falcatum (Aspidiaceae), Marattia douglasii (Marattiaceae), Sadleria cyatheoides (Blech- 
m n
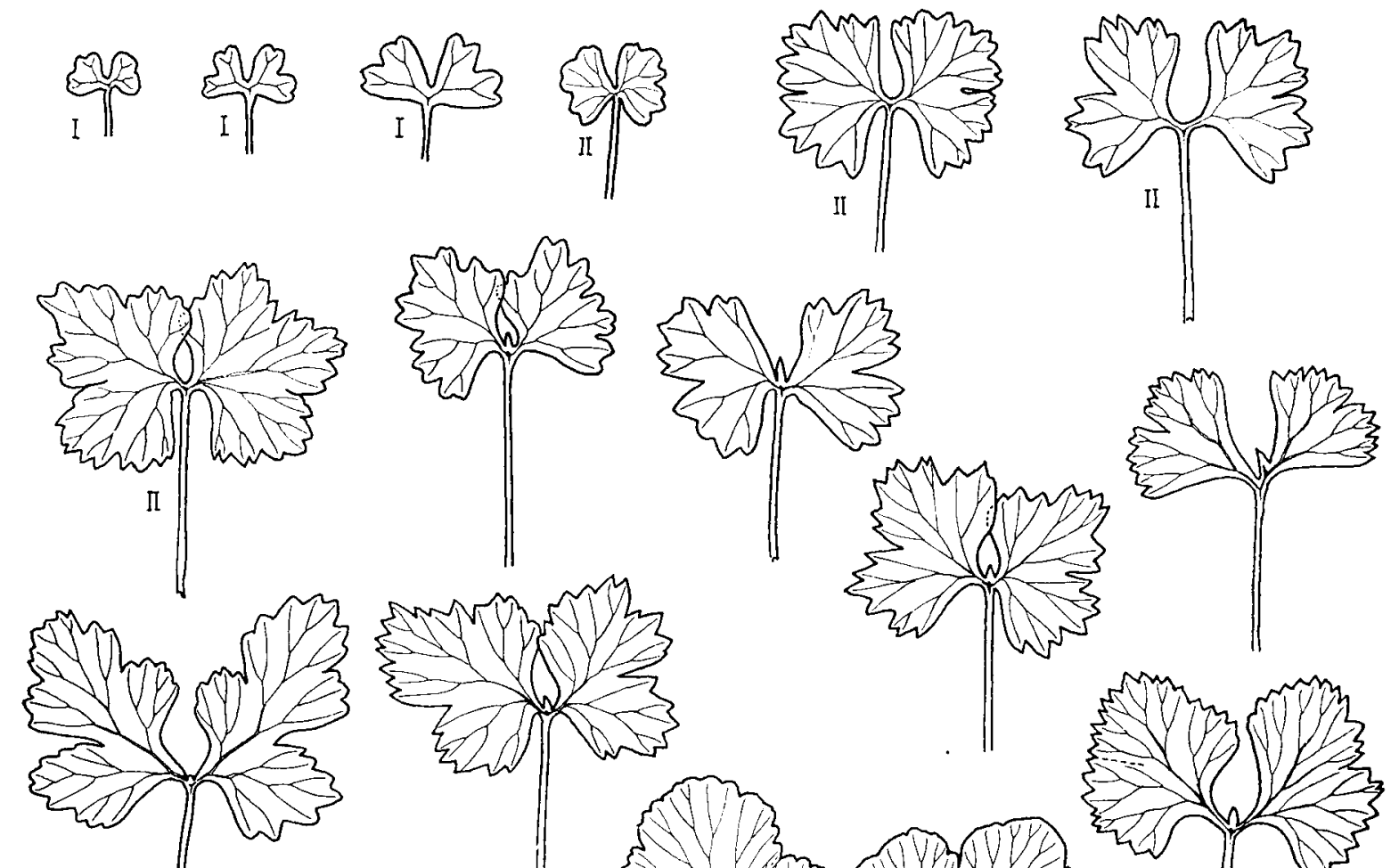

hos
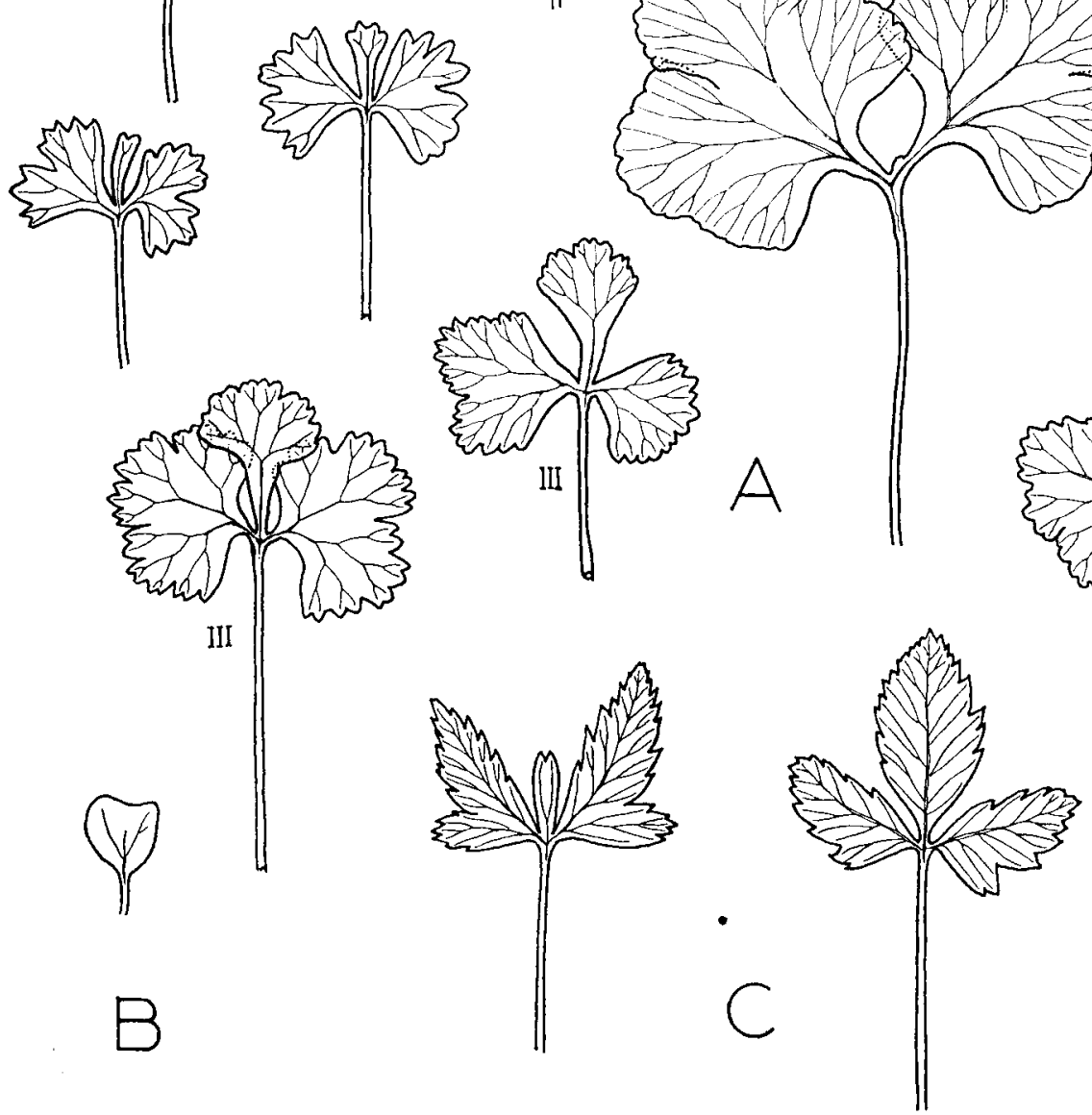

III

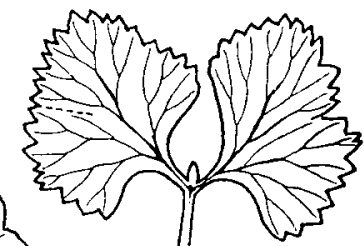


naceae), and some of those listed above. Much simplified types, such as those of Vittariaceae and Polypodiaceae do not show well-marked stages, as the transition from midribless to midribbed stages occurs very early, before the leaves attain a high degree of complexity. Other ferns, such as Pityrogramma spp. and certain adiantums (Pteridaceae), are unsuitable because the young leaves are excessively variable. In most of the ferns studied by the author, however, the following three stages are distinguishable.

Stage I.-First leaves have equally forked veins (but one side of the blade may be larger than the other). Weak individuals may have only one vein, and large first leaves from vigorous prothallia may be as complex as third or fourth leaves on other rhizomes; the first leaf by itself, or any individual leaf in a progression, therefore, is not a constant morphological entity. Stage I blades are wedgeshaped, their bases form an angle of much less than $180^{\circ}$, usually $80^{\circ}-120^{\circ}$ (exceptions being found in the osmundas). If there are four or more veinlets, those nearest the sides equal those nearest the center of the blade. With increasing complexity the blade assumes a horizontal orientation.

Stage II.-This is distinguished by changes in the veinlets which indicate lateral pinna formation. The veinlets nearest the center are longer, and often more divided than the laterals, and tend to run parallel to each other (Fig. 8B, Camptosorus). Veinlets nearest the lateral margins are shorter, and run out at a wider angle, so the blade base has a broader angle. This phase continues in sporadic fronds until there are numerous veins and distinct lobes at the two sides of the base of the blade, its angle now exceeding $180^{\circ}$. In species of Dryopteris and Asplenium (fig. 8C) Stage I and Stage II fronds are not clearly distinguished for the most part as the fronds pass quickly from Stage I to Stage III, and in more simple types such as Polypodiaceae and Vittariaceae (fig. 11), a Stage II condition is not detectable at all.

Stage III.-This is the stage of earliest midrib formation. The frond apex is emphasized; the tip of the blade is farther removed from the junction of the blade and stipe than is any point along the sides (except in rare intermediates). The longer the tip, the more strongly a midrib is evident. Midrib formation is initiated at the blade base. The veins of the bases of the lateral pinnae, or lobes, or the veins representing them, are no longer branches of a dichotomously forked system but now branch from the midrib in a pinnate manner. Further development shows increase in length of the blade-tip, extension of the midrib, and greater differentiation of lateral veins and sinuses, if present. Continued increase in complexity of most fern leaves involves merely lengthening of the blade apex and the addition of more major lateral veins or leaflets in successive fronds until the definitive mature form is reached. If the species has reticulate veins, areoles appear first in Stage II or Stage III.

The few species in which the midribless condition persists even to adult soriferous fronds can mostly be classified according to whether the pattern corresponds to Stage I or Stage II; the majority are of the latter. Stage III forms of fronds, i.e., with ternate vascular patterns, are relatively more common than the dichotomous ones among adult leaves of ferns (e.g., Asplenium cardiophyllum and Schaffneria nigripes in the Aspleniaceae, and species of Doryopteris and Hemionitis in the Pteridaceae). The known examples of midribless adult leaves of ferns (the species belonging to a total of only eight genera) are discussed below.

(1). Dipteris: Three species of peculiar frond habit are included in this Old World genus which may be distinguished as a family, Dipteridaceae. Posthumus (1929) shows that each of the major halves of the midribless blades is turned $180^{\circ}$, a fact recognized on herbarium sheets by the twisting of the adaxial ridges of the leaf stalk to the abaxial side. The leaf habit accounts for the West Javan name of "pakis payong" or umbrella fern for Dipteris conjugata. Posthumus states that illustrations of this species are misleading, as the shorter minor lobes are morphologically central rather than lateral, as usually figured. For this reason, adult leaves do not accord with either Stage I or Stage II juvenile patterns. Midrib formation never occurs at any stage in this genus (fig. 10B), but the leaves possess what, among ferns in general, is unusually complex reticulate venation, suggesting the minor venation of angiosperms.

Authors have seen in the Dipteris leaf a resemblance to the leaf of Matonia (Matoniaceae), a fern with free veins. The idea that Matonia lacks a middle pinna has persisted since the time of Diels, and both Copeland (1947) and Holttum (1949) adopted the erroneous view that the leaf is dichotomous, and remarked on its similarity to the Dipteris leaf. However, Troll (1938, p. 1523) emphasized that the leaf of Matonia has a middle pinna and is, therefore, not dichotomous. The leaf of Matonia is similar in its organization to the pedate leaves of certain pteroid ferns in which evolution has probably taken place, as indicated by Troll (1938, fig. 1269), from a typical pinnate blade. Therefore, it should be stressed again that the leaf of Dipteris differs from that of Matonia in basic plan-in spite of ex.

Fig. 7. Juvenile fern leaves: A. Osmunda cinnamomea. Numbered leaves show typical examples of stages I, II, and III; those without numbers show the papilla-condition. B. Asplenium trichomanes (single frond with short central vein). C. Pteris tremula (frond on right normal, that on left with reduced "middle pinna"). D. Athyrium filix-foemina (frond with "papilla.") 


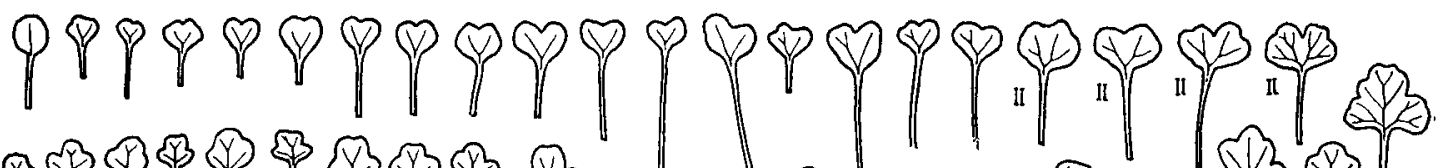

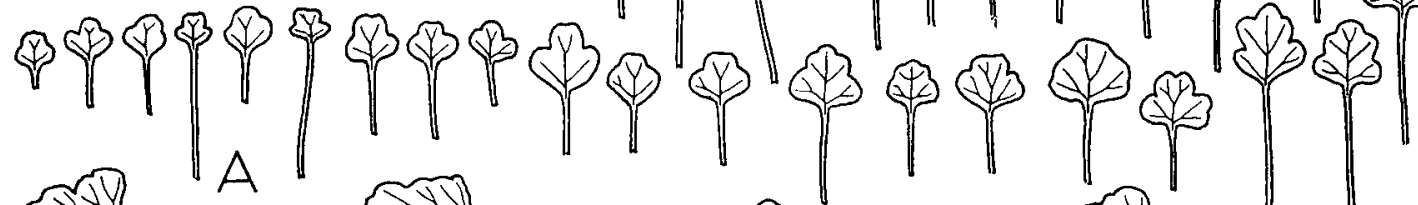

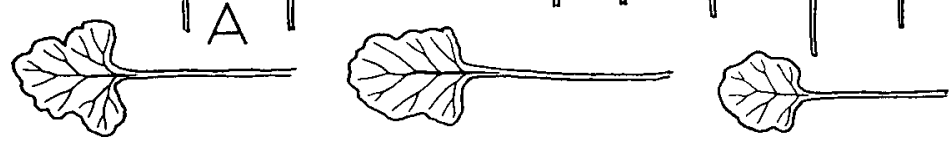

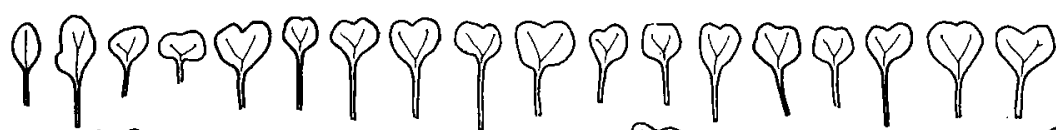

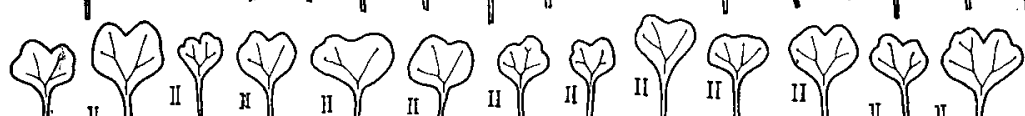
"P IP

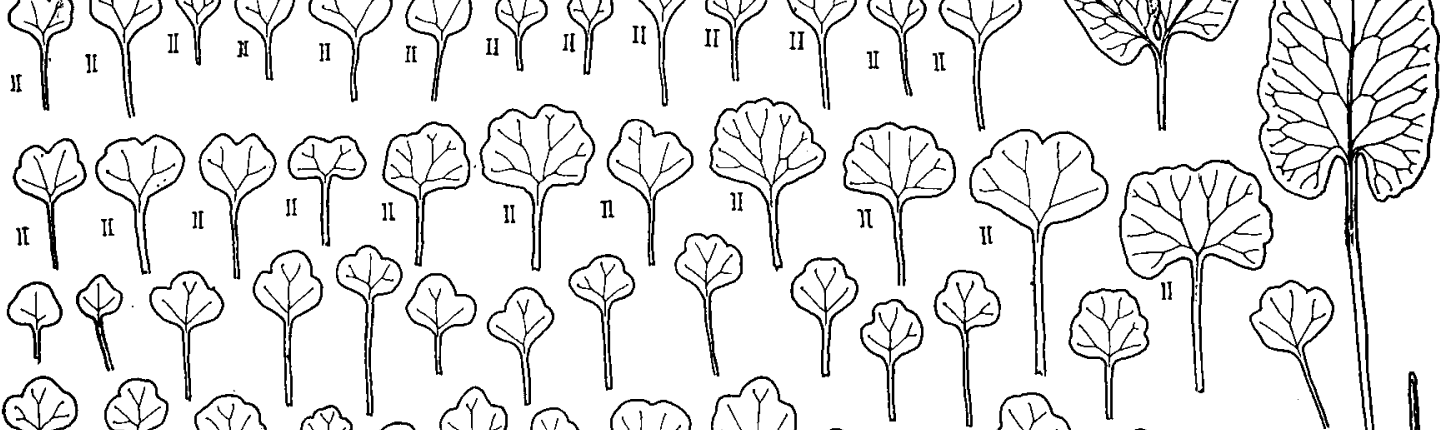

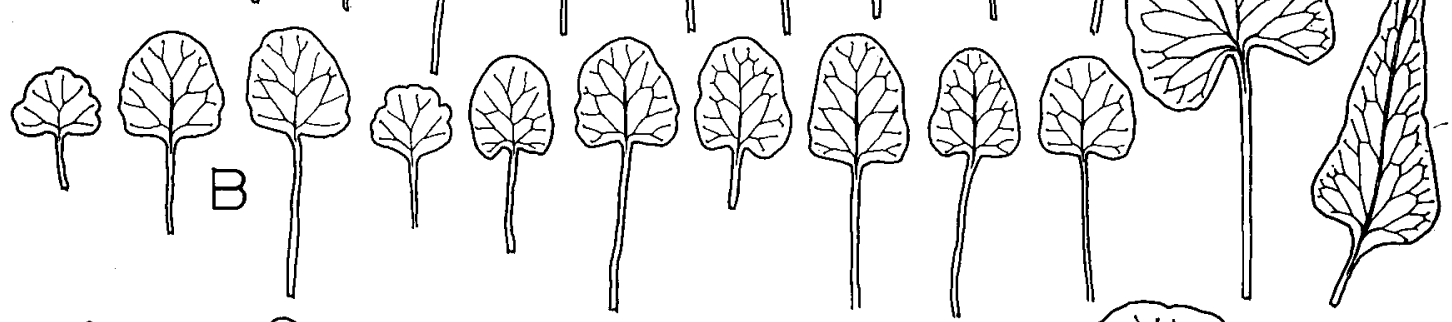

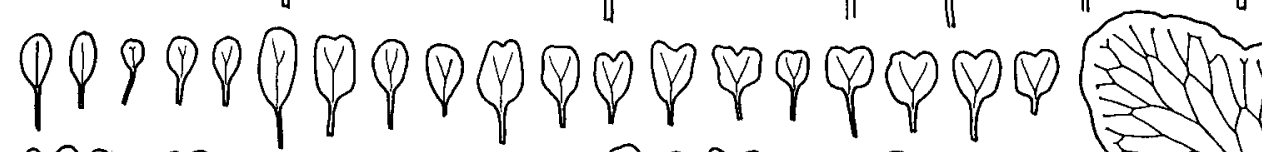

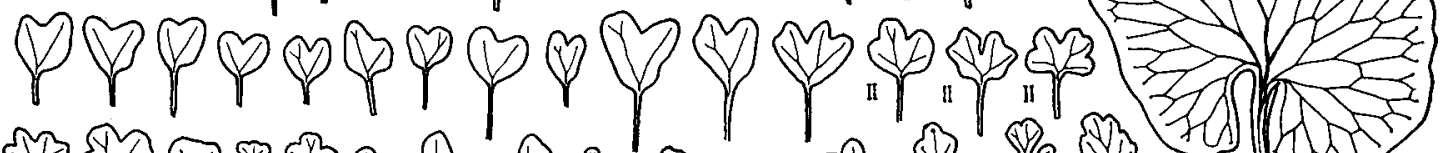

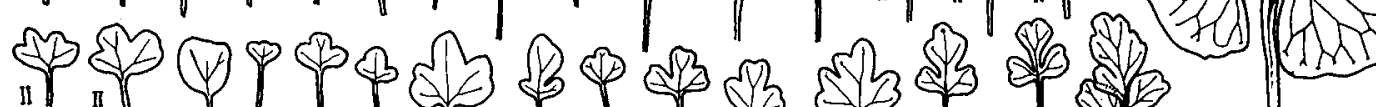

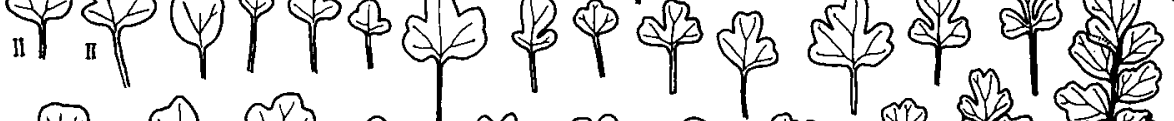
(4) 
tremely large and much modified lateral pinnae in Matonia, there is yet present a "middle pinna" continuing from the petiole. Unique features of the Dipteris leaf, its umbrella-like habit, twisted major blade divisions, absence of a blade midrib in any form, and highly reticulate minor venation, stand in sharp contrast.

(2). Cardiomanes reniforme: This New Zealand filmy-fern is unique in the Hymenophyllaceae. But contrary to Bower's view $(1923$, p. 86), the vein system is not developed with all its branches equal: the lateral and basal veins are shorter than the central and run out in the same way as laterals of Stage II juvenile fronds in general (fig. 9K). In nature its leaf assumes the form of a cup or funnel in dry weather (Verdoorn, 1938, p. 386). The inrolling of the basal leaf margins under desiccation is probably correlated with its morphology. There is no evidence that this structure is anything but specialized in the Hymenophyllaceae, and pinnate ancestry is strongly suggested by the presence of incipient lateral pinnae as indicated by venation and basal lobes.

(3). Microtrichomanes francii: The filmy-fern genus Microtrichomanes contains nine species of small ferns ranging from Malaya to Tahiti and Madagascar, which in their mature form correspond to different stages of juvenile leaves. Bower's figure (1923, fig. 504,a) of $M$. lyallii shows the Stage III juvenile blade pattern, with a short mid$\mathrm{rib}$ at the base of the blade. A wider range of forms is illustrated by Copeland's plate (1933, pl. 7): at one extreme is $M$. dichotomum, with a long rachis and several pairs of pinnae; at the other extreme is the smallest species of its group, $M$. francii (ibid., fig. 2) which has fronds that correspond to Stage I fronds as described above. These species illustrate a correlation of decrease of frond size with blade simplification, expressed finally in $M$. francii by the loss of a midrib and the assumption of a fan-like outline.

14). Adiantum reniforme and A. parishii: The maidenhair-ferns, Adiantum, comprise about 200 species, of which only two lack morphological midribs in the adult condition. The frond structure of $A$. reniforme ( $\mathrm{fig} .9 \mathrm{~J}$ ), of Madeira, and A. parishii, of Moulmein, corresponds in the adult state to Stage II juvenile fronds; Stage III intermediate leaf types, as illustrated in Microtrichomanes and in the three genera to follow, are apparently lacking.

(5). Lindsaea reniformis: This fern provides a graphic illustration of evolutionary changes in adult leaf-form that may lead to species in which the midribless condition is attained. Lindsaea reniformis (fig. $9 \mathrm{H}$ ) has fronds corresponding to Stage II juvenile leaves, i.e., no midrib is formed. But the very closely related $L$. sagittata (fig. 9I) has typical
Stage III fronds with a short midrib. These two entities belong to a large genus of the same magnitude as Adiantum, but all the remaining species have pinnate leaves. Posthumus (1926) concluded that $L$. reniformis should be considered merely a form of L. sagittata.

(6). Actiniopteris radiata: The fan-shaped, deeply dissected blades of this species, the folding mechanism in dry weather, and the spirally-thickened epidermal cell walls of the lamina (Ogura, 1938) collectively indicate leaf specialization. The fern, a xerophyte of the region from South Africa to India, is related to cheilanthoid-gymnogrammeoid ferns, of which all, execpt this and one species of Pterozonium, have midribbed fronds. Copeland has written (1947) that "as to probable affinity, Actiniopteris has more in common with Doryopteris [a genus with short, ternate, Stage III fronds for the most part] than with any other genus." In its successive leaves (fig. 10A) this species passes from typical Stage I condition (as seen in the related genera Doryopteris and Pellaea, for instance) into Stage II, where it remains without any tendency toward midrib formation; Stage III has been completely eliminated. In this case, the formation of a deep central sinus prevents further change from Stage II.

(7). Pterozonium reniforme: Pterozonium is a small tropical American genus of five species, four with simple-bladed leaves, those of one species, $P$. reniforme, lacking a midrib. The relationships of this genus, like the foregoing, are with cheilanthoidgymnogrammeoid ferns, and particularly with the pinnate-fronded New World genera Eriosorus and Jamesonia. Pterozonium conforms with these genera in spores, sporangia, soriation, venation, paleae, range, and other features, and may not be entirely distinct from certain elements in them. A transitional series occurs in these genera, from the strictly erect, narrowly linear, multipinnate fronds of certain species of Eriosorus and the species of Jamesonia to short, simple fronds in Pterozonium that correspond to Stage III fronds, and finally to $P$. reniforme which is midribless and like Stage II juvenile fronds. Pterozonium cyclophyllum (Goebel, 1929, fig. 15) corresponds to Stage III in having a short midrib. A species of this genus has been described ( $P$. spectabile Maxon and A. C. Smith, in Gleason and Killip, 1939) in which the fronds "grow up," so to speak; there are 20-24 alternate pinnae, each of which "resembles the entire blade of the previously described species." Both from inter- and intra-generic comparison, therefore, the mature blade of $P$. reniforme appears to be an evolutionary end-point, and to represent a frond which has lost the ancestral capacity to form a midrib.

(8). Rhipidopteris: Another end-point of special-

Fig. 8. Juvenile leaves of increasing complexity, the st ge II fronds marked: A. Asplenium pinnatifidum, Virginia (older stages horizontal). B. Camptosorus rhizophyllus, M iryland. C. Asplenium trichomanes, Maryland. 


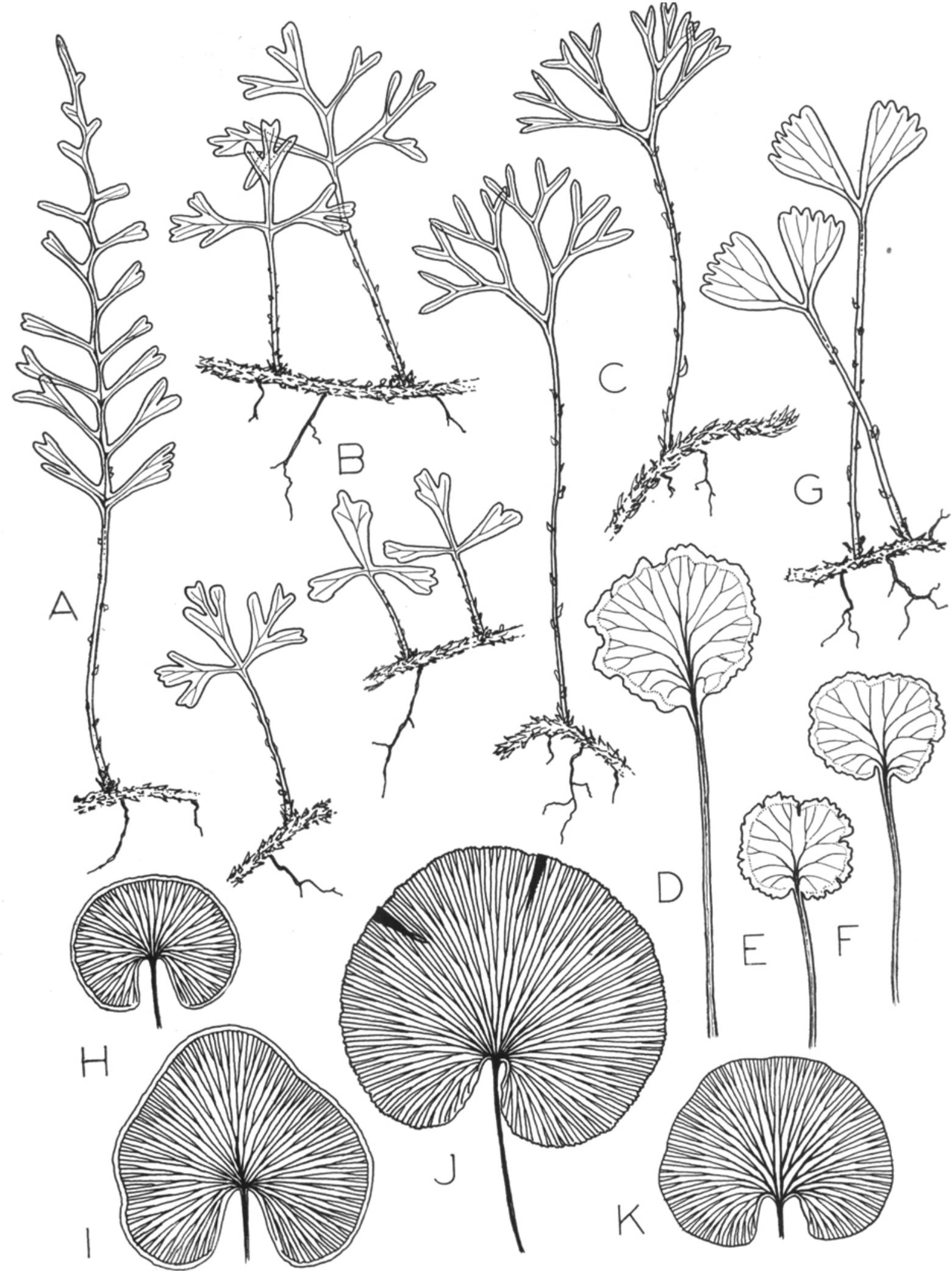


ization is suggested in the New World tropical genus Rhipidopteris, three of the species of which possess sterile fronds with the vascular architecture of Stage I juvenile fronds (fig. 9, C, G). The fourth species, $R$. tripartita (fir. 9B), has deltoid sterile fronds with one pair of lateral pinnae, essentially as in Stage III. Two other apparently closely related ferns, Microstaphyla columbiana (fig. 9A) and $M$. moorei, are like $R$. tripartita in having a midrib, but their fronds are oblong with many pinna pairs. ${ }^{3}$

If the three species, $R$. flabellata, $R$. peltata, and $R$. foeniculacea may be regarded as midribless endpoints of evolution in the series of plants mentioned above, and the latter are derivatives of the enormous and diverse, pantropical genus Elaphoglossum of 400 species, all with midribbed fronds, then a reasonable reduction series can be postulated. It would be supported by the fact that the fertile fronds of the throe species with midribless sterile fronds do possess midribs, and thus correspond with Stage III fronds (fig. 9, D, E, F, fertile fronds of different collections of $R$. peltata). In these cases the sterile fronds have apparently become reduced to the form of Stage I, but the fertile fronds have "lagged behind," and still produce short midribs.

B. DISPLACED-MIDRIB TYPE. - The maidenhair fern common in North America and Asia, Adiantum pedatum, undergoes a strange sequence from a pinnate leaf-type normal for the genus to a dichotomous state (fig. 3 ). In the mature frond the blade axis forks directly above the petiole, forming a dichotomy. Slosson (1906, p. 9) showed that, "in the mature stages a single leaflet is present below the basal pinnae on one half of the dichotomous rachis. There appears to be nothing about the leaf at this stage of development to account for its presence and no corresponding leaflet on the other half of the dichotomous rachis." The earlv leaves, however, are clearly pinnate; in the following leaves, one of the basal lateral pinnae becomes enlarged and re-oriented, and the rest of the blade, including the midrib, is correspondingly changed so that the enlarged basal pinna finally equals the rest of the blade; it becomes a mirror image except for the tell-tale extra pinnule on the pinna shank of the dichotomy. The midrib thus becomes displaced laterally so that it duplicates the main axis of the enlarged pinna. This condition is found also in the

3 These two so-called Microstaphyla species seem related to Rhipidopteris, rather than to true Microstaphyla, i.e., $M$. furcata, of St. Helena, which differs from these two American ferns as well as Rhipidopteris species in its narrow, wiry stipes, closely borne on a compact, short-creeping to suberect stem, in lacking scales on stipes and blades, in the distinct scale structure, in the color and texture of lamina, and in the dissection of the fertile blade.
Mexican A. patens and the Old World A. hispidut lum.

Doubt may exist whether this category is coordinate with the others, but since the form of the major vascular axes of these leaves so closely approximates a perfectly dichotomous system, it is at present maintained as one of the categories of foliar dichotomy derived apparently from pinnate leaves.

C. CRESTED-BLADE TYPE. - This form of foliar dichotomy is found chiefly in horticultural varieties. It may be characterized as follows: (1) forking of main veins or divisions of the blade irregular and apical, (2) cresting increases with size of leaf, and juvenile foliage in known cases is not forked, (3) the fronds of wild examples are, with one exception, pendent from epiphytic or epipetric rhizomes. Species with leaves normally of this type number only 26 , but forking or eresting of the tips of the leaves of other species is familiar as a common abnormality. It is surprising that the similarity of the few cases in which this type occurs normally has not been recognized. In Costa Rican rainforests, for instance, a species of Ctenopteris (Grammiti. daceae) has fronds with each of the lateral pinnae irregularly forked once or several times. Its appearance suggests a pendent, aerial seaweed, hence the specific name fucoides. The recently described Calymmodon ramifer, a member of the same family occurring in New Guinea, also has divided pinnae, which, like the foregoing, are unique in its genus. Such forking, whether affecting pinnae only or the blade axis itself, always appears somewhat haphazard; it is not comparable to the regular dichotomous branching of Fucus (Phaeophyta) or of Psilotum (Psilopsida), which follows a definite pattern, and results in branches of nearly equal size. Crested fern leaves, therefore, usually appear monstrous. Basically their structure is like other fern leaves; they are pinnate (sometimes reticulate) in vascular pattern, and the crested condition is superimposed upon the normal structure. The known young leaves of naturally occurring crested ferns are like those of their near relatives in basic architecture, and in stages corresponding to Stage III and beyond, possess midribs and lateral veins. In maturity the apical forking appears.

The forked leaves of ferns are morphologically different from the two-topped monstrous leaves found occasionally in angiosperms. The latter are traceable in origin to irregular phyllotaxis, where separate leaves become fused together so two blades or blade tips arise from a fusion-petiole or fusionmidrib (Schoute, 1936). Crested or forked fern leaves, on the other hand, are apparently due to peculiarities of their own meristematic apices.

Fig. 9. Fern leaves: A. Microstaphyla columbiana, Colombia, Killip 11365. B. Rhipidopteris tripartita, Andes, Johnston 207. C. R. peltata, Dominican Republic, Abbott 1853. D. R. peltata, Guatemala, Heyde \& Lux 1892. E. R. peltata, Mexico. F. R. peltata, Nicaragua, Maxon 7794. G. R. flabellata, Peru, Killip \& Smith 23206. H. Lindsaea reniformis, Brazil-Venezuela border, Holt \& Blake 494. I. L. sagittata, Surinam, Maquire 24817. J. Adiantum reniforme, Teneriffe. K. Cardiomanes reniforme, New Zealand, Prince. 


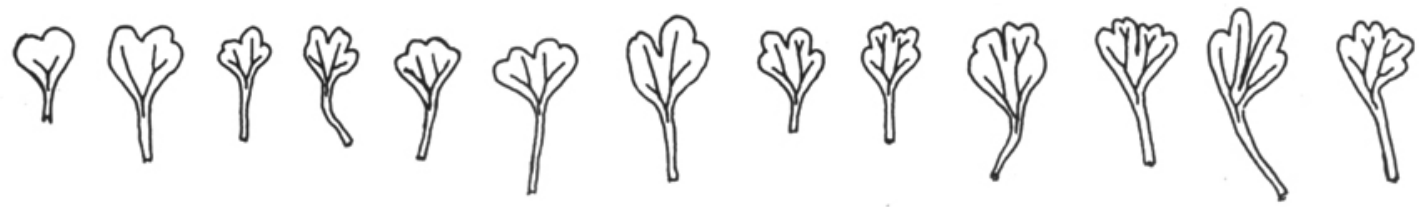

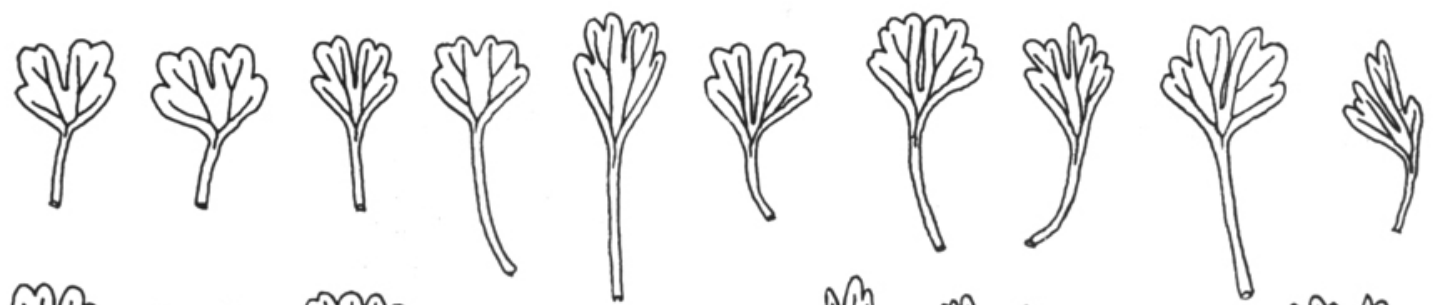
湓
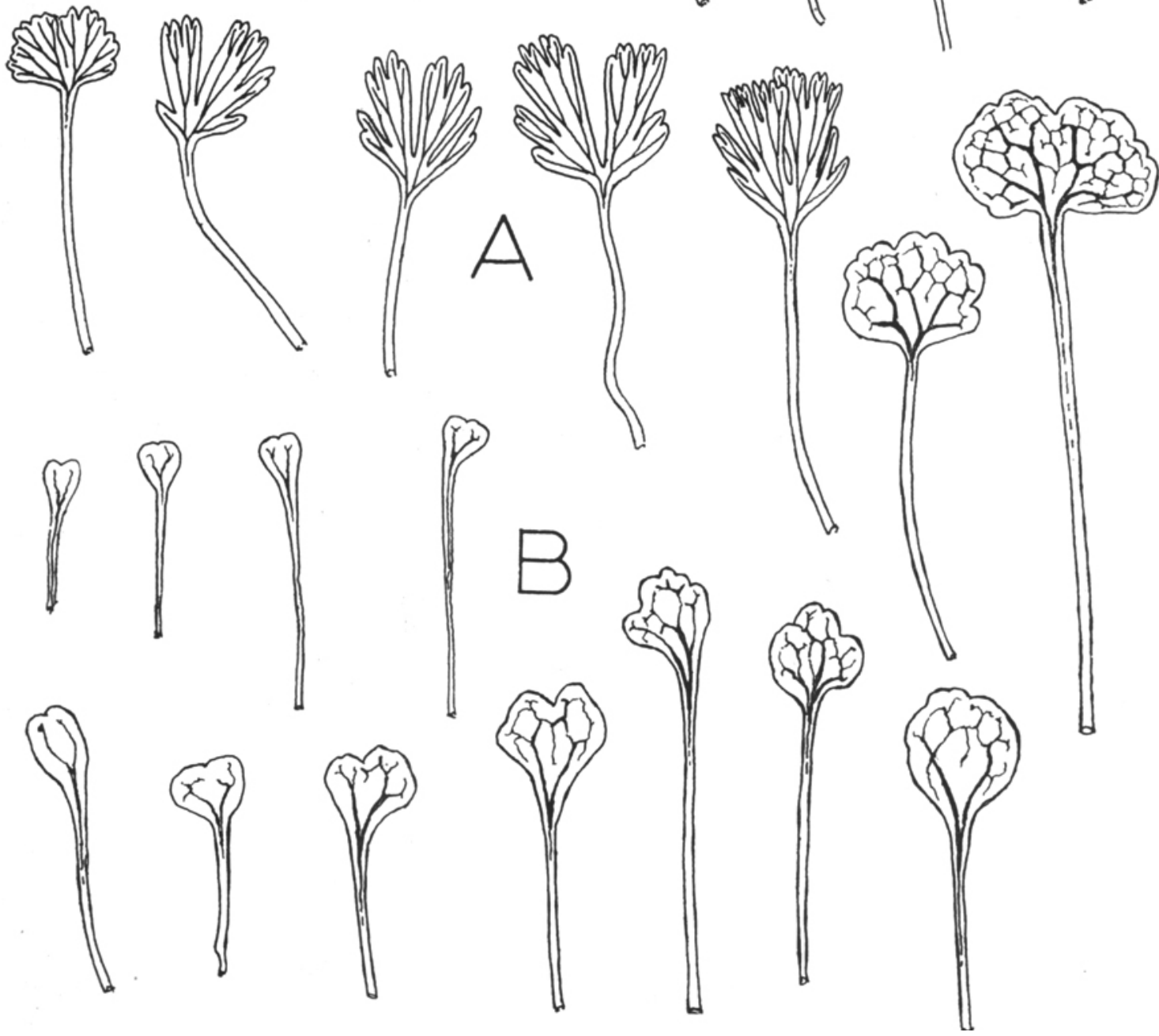

Fig. 10. Juvenile leaves in order of increasing complexity: A. Actiniopteris australis. B. Dipteris conjugata. 
In horticulture, depending on the number and intervals of such branchings, leaves are termed "forked," "crested," "ramose," or "plumose." But each of these conditions is probably caused by the same phenomenon. Such leaves may arise as mutations of greenhouse ferns, and may be propagated by buds or spores, depending on the species. Books of fern varieties (e.g., Lowe, 1867) illustrate many such forms; over half of the nearly 200 described horticultural varieties of the European Scolopendrium vulgare (Aspleniaceae) involve this condition. Rarely such aberrant ferns escape from gardens and establish themselves in nature, for example, the fishtail-fern, Nephrolepis biserrata var. furcans in Hawaii, and $N$. cordifolia var. duffii in the Caribbean. Similar fronds occur as occasional monstrosities in practically all ferns in nature. When such specimens are found they are sometimes described as new species: for example, Pyrrosia cornutus (Polypodiaceae), known from a single plant, appears to be merely an extravagant form of $P$. adnascens; when the crested plant was collected, however, the normal form was not found near by. An individual of Elaphoglossum hirtum (Aspidiaceae) from the Hawaiian Islands (Maui, Hannah Lou Bonsey, U.C.) has all its fronds repeatedly forked, but the normal form of the species occurred in the vicinity. Either or both of these examples could represent genetically fixed mutations. Andersson-Kottö studied some crested ferns in horticulture and demonstrated in these that the condition was genetically controlled (in Verdoorn, 1938). Fronds showing the crested condition in the wild state may be selected by factors of the epiphytic habitat or may be able to persist in the epiphytic state, for, with one exception, all known naturally occurring examples are epiphytic or epipetric ferns, the leaves of which hang down from damp rock cliffs or from crotches or branches of forest trees.

Tryon (1938) examined 300 naturally occurring forked fronds and showed that forking occurred most often at the tips of the segments. Of 808 forked segments ("segments" in this case referring to either whole blades or pinnae), he found that 678 were forked at the tip, 109 in the middle, and 21 at the base. Cresting has been produced experimentally by slitting frond tips longitudinally. Branching results, and pinnae and (or) lateral veins also develop on the side facing the slit above the older portions of the cut surface (Williams in Verdoorn, 1938, bibliography). Leaf meristems in ferns differ from those of angiosperms in an important respect: in angiosperms, leaves are formed from division products of an ultimate group of initial cells, but in ferns from only a single apical cell at the apex of a primordial blade or pinna. If this is destroyed by slitting, damage, or abortion (or, if it undergoes a chance equivalent division), a forking will occur. The multiple apices so produced, however, are the same in structure as the single apices of normal leaves of the same or related species. The following list mentions only those fern species in which branching involves the main axis of the blade.

(1). Ctenopteris heteromorpha: Found in various places from Mexico to Ecuador, this fern of the Grammitidaceae is unique in its genus (of about $200 \mathrm{spp}$.) in having crested rachises. Its fronds are forked at any position along the blade, often many times (fig. 4). It grows in high rain-forests at elevations around $10,000 \mathrm{ft}$. on vertical banks under waterfalls or in sheltered niches and grottoes of cold cliffs. "So variable are the specimens from the same tuft, as gathered by Professor W. Jameson 'upon the top of the mountain Pichincha, growing in large patches, straggling or hanging over the face of the dripping rocks,' that if several of them were seen separately they might well be supposed to constitute distinct species." (Hooker and Greville, 1828). The variable cresting in this species amplifies the leaf surface. Another fern, Ctenopteris variabilis, is superficially so like C. heteromorpha that Christensen called them the same species. The leaf of C. variabilis, which occurs in similar habitats, has also been amplified, but by irregular elongation of lateral pinnae, so that effectively as many major branches occur in the one species as in the other. The same "end" has been reached by different means, in one case by repeated forking of the apex, in the other by the irregular elongation of the lateral pinnae.

(2). Grammitis furcata: This exemplifies several species of Grammitis (a genus of $140 \mathrm{spp}$.) which show cresting. The fronds of this genus are simple with pinnate veins and are normally strap-shaped, with a midrib running the length of the blade. $G$. furcata is epiphytic in forests from Trinidad to Brazil; its fronds are only 2 or $3 \mathrm{in.} \mathrm{long}$ and sometimes simple, but usually irregularly forked. Forking may occur only once, or one or both of the branches of the blade may te again forked, and the positions of the furcations are obviously not fixed.

(3). Platycerium: The staghorn ferns of the Old World tropics number 17 species. The leaves of these epiphytes are of two forms-flat, rounded, humus-collecting ones which grow tightly against supporting boughs of trees, and long, pendent, photosynthetic leaves with patches of erowded sporangia. The latter are usually forked, often many times. Such features as dictyostelic rhizomes, articulate stipes with numerous vascular strands, broad paleae, stellate-pubescent laminar surfaces, stellate paraphyses, erect annulus of the sporangium, and elliptic spores show that the genus is related to the polypodiaceous genera Pleopeltis and Pyrrosia. Leaves in those two genera, however, are mostly simple with unbranched midribs, although Pyrrosia has a tendency for sori to become fused into patches, and for the fronds to be dimorphic 
(and rarely crested). In Platycerium juvenile leaves are rather like the leaves of Pleopeltis and Pyrrosia; they have one midrib and do not branch apically. The venation of Platycerium in all stages is reticulate, rather than open as in Grammitis and Ctenopteris.

(4). Cheiropleuria bicuspis: The characters of this fern are combined so peculiarly that it may be treated as a family, Cheiropleuriaceae. The one species is a terrestrial plant ranging from Okinawa to Tonkin, China, and New Guinea. Solenostelic stems, non-articulate stipes with but two vascular strands, indument of hairs rather than scales, glabrous laminar surfaces, capitate paraphyses, and obliquely annulate sporangia with stalks of four rows of cells are characters which, taken together, mark it as a primitive fern. But the leaves are of a specialized form. The complexity of the venation approaches that in flowering plants. The fronds are dimorphic: the fertile frond has a midrib, with lateral veins running out on either side; and the sterile frond lacks a definite midrib, being, in most populations, once- or twice-forked. Fronds of juvenile plants resemble fertile adult leaves in structure, being undivided and conspicuously pinnate-reticulate in vascular architecture.

(5). Ophioglossum pendulum and O. palmatum: With the exception of Ophioglossum pendulum and $O$. palmatum, all our most primitive living fernsMarattiaceae, Ophioglossaceae, and Osmundaceae-have pinnately-veined, midribbed leaves, as do ferns generally. Practically all Ophioglossaceae have the unique foliar feature of the so-called "fertile spike" which is apparently the fusion product of two basal pinnae. It is generally agreed that the Botrychium leaf with its pinnate structure and free veins exemplifies the elementary type which led to the reticulate-veined leaf of Ophioglossum. The only two species of the family which have crested leaves are also the only ones of 220 species and 12 genera of the three primitive families which are epiphytes.

The first, $O$. pendulum, hangs in great kelp-like masses from boughs of trees over a wide range in the paleotropics. It commonly grows in massive rhizomes of bird's-nest ferns (Asplenium nidus). The juvenile leaves are simple, but very long mature fronds are often forked. The condition is variable and occurs only in the largest fronds where sterile blades may be forked as many as three times. The "fertile spike," the stalk of which is fused with the ribbon-like sterile blade, may rarely itself be forked, especially in Philippine populations.

The "hand-fern," O. palmatum, occupies in the neotropics a habitat like the foregoing; as I have found it in Puerto Rican rain-forests, it tends to hang from root-masses of bromeliads. The position of the frond, as in $O$. pendulum, is vertical, but its broad blade surface, unlike the other, is parallel rather than perpendicular to the supporting surface. o. palmatum has attracted much attention, and some authors have even suggested that the leaf of this monstrous epiphyte represents the parental type of the 24 species of common adder's-tongues, Euophioglossum, which occur terrestrially and have leaves oriented like those of Botrychium. Bower (1926, p. 50), on the contrary, considered $O$. pal. matum to be derived from ordinary adder's-tongues by amplification. His view was not accepted by some authors, including Chrysler and Eames. Chrysler (1941, p. 16) has stated his reasons for considering $O$. palmatum the ancestral type-"In Ophioglossum palmatum the repeated dichotomy shown in juvenile stages and also in many adults appears like the persistence of a very ancient habit." However, I have not seen dichotomy in the juvenile stages of this species. Chrysler's fig. la (also Campbell, 1940, fig. 159) shows the juvenile leaves to be simple and to conform with their uncrested terrestrial relatives. Even early fertile fronds may be simple as illustrated by Gray Herbarium specimens (Cuba, Wright 946; Dominica, Howard), where not only sterile but fertile segments are like Euophioglossum. In $O$. palmatum the young leaves clearly show progression from the usual adder'stongue type to the unusual one. Chrysler (loc. cit.) also states that "the spikes with their truly lateral (marginal) position may represent specialized lobes"; but his figures show that the spike first appears as a medial, simple structure, its stalk fused to the center of the blade. Succeeding fronds show it forked into two "spikes" and these branched and reoriented so as to appear to be borne on the margins. Ontogeny, therefore, strongly supports the evidence derived from comparison within the fam. ily and from the generally accepted view of the nature of the ophioglossaceous spike: the multiple marginal spikes are evidently due to repeated forking and reorientation of a single medial spike.

Because of an apparent "mid-vein" in certain terrestrial adder's-tongues, Chrysler argues that these must be specialized as contrasted with $O$. palmatum where no "mid-vein" is suggested. However, as either "mid-veins" or rachises occur in most ferns, including Botrychium, it is more logical that loss of such structures would be a specialization, as it certainly seems to be in the pendulous fronds of certain of the species of Antrophyum (Vittariaceae). Regarding vein pattern, Chrysler indicates that the network in $O$. palmatum is simpler than in some species of terrestrial Euophioglossum, but the species he refers to and figures are only four out of 24 , and these have a peculiar "double venation" with minor areoles within major ones. These species seem, therefore, too divergent to bear much weight in a general comparison. In further support of his view, Chrysler cites teratological, typical adder's-tongues with crested sterile segments. But since, as discussed earlier, such abnormalities are found in practically all ferns and appear to be related to leaf-forming meristems, I agree with Bower 
that "these changes are no more suitable material for direct argument ... than are the stamens or carpels of monstrous angiospermic flowers." (1926, p. 50).

Eames (1936, p. 118) shows a hypothetical evolutionary sequence in Ophioglossum, beginning with $O$. palmatum (O. palmatum, O. pendulum, O. vulgatum, $O$. lusitanicum, and $O$. simplex), and, parallel to this series, "a reduction series" in Botrychium (B. virginianum, B. dissectum, B. matricariaefolium, $B$. lunaria, and $B$. simplex). Chrysler (op. cit.) stated that "a reduction series starting with $O$. palmatum duplicates the series which seems to be very probable in the genus Botrychium." In what respect do these "series" duplicate each other, however, except in sizes of leaves involved? In Botrychium the major change concerns size alone, but in the Ophioglossum series new differences in leaf architecture arise. It is, therefore, questionable whether the Ophioglossum series duplicates the other, for when all the evidence is considered it seems more likely that $O$. palmatum is the specialized and derived element, adapted for epiphytic, pendent existence through amplification of the leaves by cresting.

(6). Hecistopteris pumila: Finally may be mentioned Hecistopteris pumila, a tropical American epiphyte which is the sole representative of the Vittariaceae, a pantropical family of nine genera and 140 species, with fronds other than pinnate in plan. Its leaves are less than an inch long and only a quarter or a third of an inch broad at the dichotomous tips. Williams (1927) studied the family and concluded that the genus Vittaria is the primitive element, although Goebel had earlier assigned this position to Antrophyum. But Bower (and Holttum) consider Hecistopteris the primitive element, in which "all its leaves are of the nature of juvenile leaves; they never get beyond that state, but bear sori even upon an open venation" (1928). Juvenile leaves of the Vittariaceae (fig. 11A, B, C, F) are, however, quite unlike the Hecistopteris leaf (fig. 11G). The individual forked frond of Poly. taenium lineatum figured by Bower (1928, fig. 746c, as Antrophyum lineatum) is evidently teratological, for although crested fronds are frequently found in mature plants, they are rare in juvenile specimens. Not a single other example of veins forked more than once was found in juvenile plants of this family (see also Williams, op. cit.). Furthermore, such species as Antrophyum immersum and $A$. nanum actually do retain the juvenile morphology in mature, fertile leaves (fig. 11, D, E). In the Hecis.
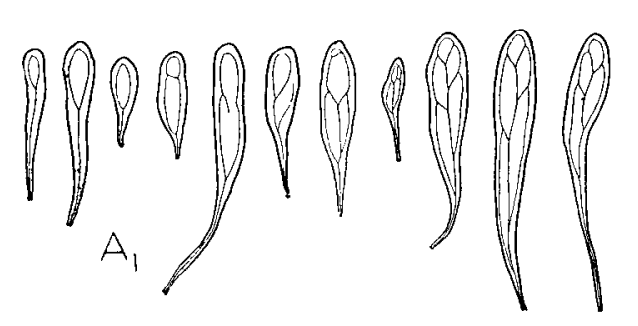

(1)
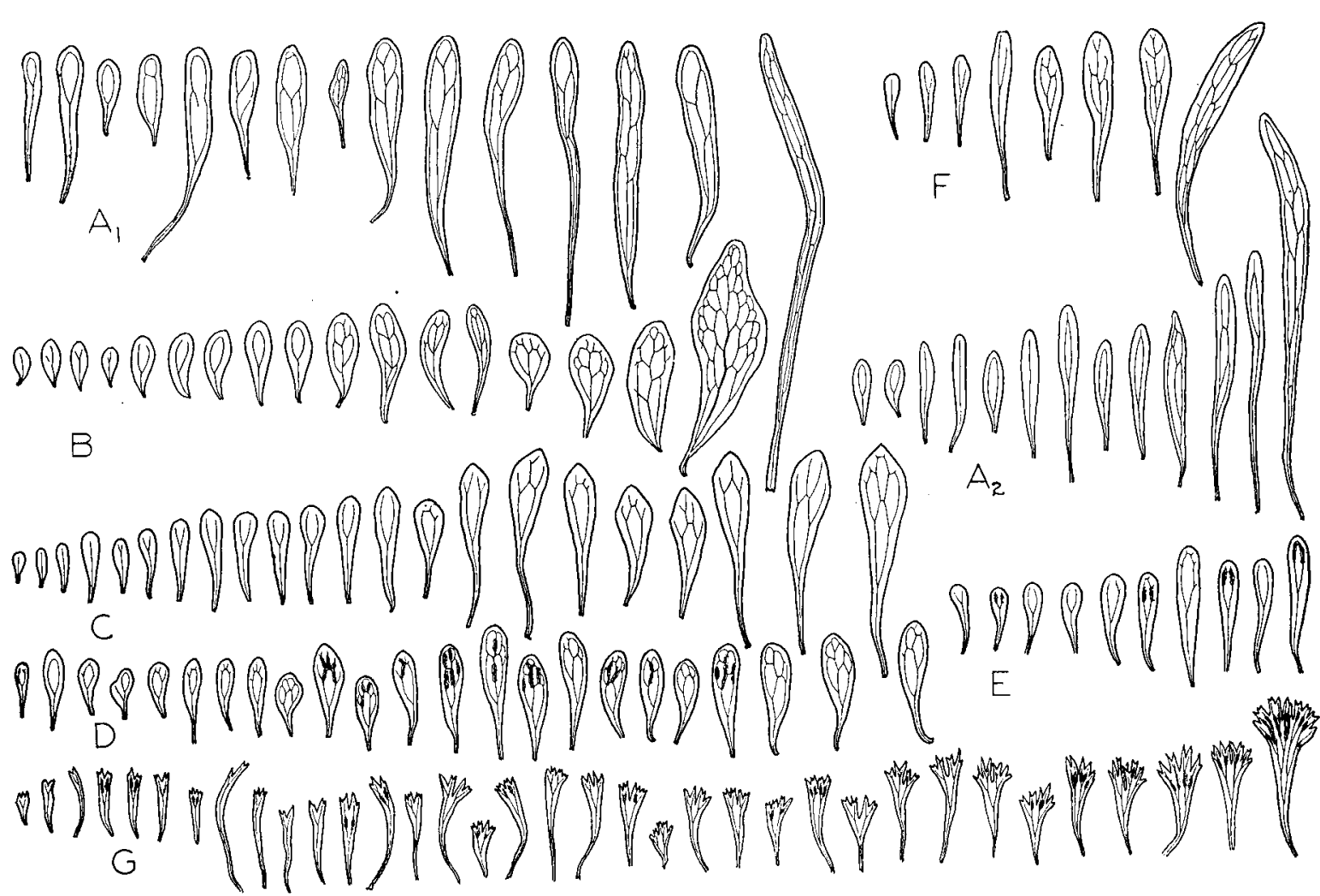

Fig. 11. Leaves of Vittariaceae. The dark patches along the veins represent sori: $A_{1}$. Vittaria lineata, Dominica, Howard 1446. A . V. lineata, Venezuela, Broadway 717. B. Ananthachorus angustifolius, Trinidad, Fendler. C. Antro. phyum petiolatum, China, Tsiang 4624. D. A. immersum, Mindanao, Elmer 11090. E. A. nanum, Mindanao, Weber 1514. F. Polytaenium lanceolatum, Santo Domingo, Tuerckheim 3013. G. Hecistopteris pumila, Guatemala, Watson. 
topteris leaf, two peculiarities indicate the cresting type of dichotomy: the branching of the blade is distal, and it is irregular-so irregular, in fact, that no two fronds are exactly alike. Whether the earliest leaves of young sporophytes are crested is still not known.

D. FORKED-PETIOLE TYPE.-The curly-grass fern, Schizaea pusilla, of Newfoundland, Nova Scotia, and New Jersey, has been called by Wherry "the most un-fernlike of our native ferns." It is the northern representative of a genus which ranges as far southward as New Zealand. All schizaeas have peculiar frond habits - some with the leaves tall and "stick-like" (S. robusta), or flat and spiralled (S. spirophylla), or irregularly forked ( $S$. incurvata), or regularly and symmetrically forked, either deeply dissected (S. dichotoma) or with flat, bladelike expanses ( $S$. flabellata). Some authors see in the dichotomous species a primitive state, despite morphological features which suggest the contrary. The Schizaeaceae comprise five genera, Schizaea, Lygodium, Anemia, Coptophyllum (often considered a subgenus of Anemia), and Mohria. The last three have relatively undistinguished leaves, basically like ordinary ferns, but Lygodium develops twining leaves that grow indeterminately as much as $50 \mathrm{ft}$. high in trees. The family is recorded as far back as the late lower Carboniferous. The fact that its earliest fossils show typically pinnate leaves casts doubt on the possibility that dichotomous Schizaea leaves retain an ancestral character. All other evidence indicates that dichotomous Schizaea leaves are greatly specialized.

Taxonomically, Schizaea comprises three sections: Euschizaea, Actinostachys, and Lophidium, the first and last divisible into subsections. Selling (1944), in a study of the spores, listed 30 species (and has since described several more). Euschizaea subsect. Pectinatae, with eight species, possesses "simple and undifferentiated" leaves; the fertile segments are pectinate in arrangement, i.e., comb-like. Subsection Biffdae, with two species, differs in having irregularly forked leaves. Euschizaea is regarded as the primitive section of the genus on the basis of a number of characters (op. cit., p. 11). Of the two other sections, Actinostachys, comprising 14 species, has only simple fronds and differs chiefly from Euschizaea in that the midrib of the fertile part of the leaf is so much shortened that the segments seem to arise from a point (i.e., digitately). The other, Lophidium, with nine species, differs from Euschizaea in having fronds that are consistently and regularly dichotomous, with more or less webbing between the divisions.

Of the species of Schizaea, therefore, two-thirds, including most of the section considered most primitive, and the entirety of another, have leaves that are undivided below the fertile portion of the frond. Thus the majority have long, stalk-like lower portions of the leaves terminated by opposite, much- contracted rows of fertile lobes or pinnae, each pinna having a central vein. But in basic plan this structure is not different from other ferns: there is a stalk or petiole topped by what must be interpreted as a blade divided into fertile lobes or pinnae, specialized in Schizaea wholly for reproduction. In the dichotomous schizaeas the number of individual blades is increased by forkings of the petiole.

Reproductive modification of blades and (or) pinnae, to the point of eliminating photosynthetic lamina, is a specialized state in ferns, of which all degrees occur in this family. The South African Mohria is unspecialized, the sporangia are marginal on normal photosynthetic laminae. In Coptophyllum, of tropical America, the fronds are dimorphic, some entirely fertile, others entirely vegetative; $C$. wrightii (fig. 5) has the sterile blades reduced to a mere rosette at the base of the plant and the petioles of the fertile fronds extremely long, with a few terminal, sporangium-bearing segments. Anemia, of Africa and the New World tropics, is characterized by modification of the basal pinnae only, these fertile and borne erect. In Lygodium some species bear groups of sporangia on lobes of otherwise unmodified photosynthetic pinnules (e.g., L. circinatum), and others have entirely modified pinnules (L. palmatum) which wither away completely after spore discharge. In Schizaea no species is yet known with unmodified fertile laminae. The Schizaea condition of extremely long petioles and much-reduced fertile blades is found also in fertile fronds of Ela. phoglossum squamatum, in Rhipidopteris, and in other unrelated ferns. As in Schizaea, the fertile blades tend to be more or less conduplicate. Grammitis interrupta, of New Guinea, with simple longpetioled leaves, is remarkably like certain species of Schizaea.

In the two schizaeas that have been studied, there is no blade formation at all in juvenile leaves, a condition unlike practically all other ferns. Both $S$. robusta and $S$. pusilla have needle-like earliest leaves that grow by an apical cell. In S. robusta (fig. 6) no structure comparable to a blade forms until the plant reaches the reproductive stage. Schizaea pusilla differs in having two kinds of leaves in the adult state: sterile green leaves which resemble the juvenile ones in lacking a blade, and tall fertile leaves with a blade.

The minority of schizaeas that have foliar dichotomy very likely arrived at this condition secondarily in evolution. An amplification of the original Schizaea leaf is accomplished by petiolar forking. More primitive dichotomous types (sect. Euschizaea subsect. Bifidae) have irregular furcations, but the others (sect. Lophidium) show great regularity. Webbing in some species forms a blade-like expanse of photosynthetic tissue. Lateral photosynthetic flanges occur in simple-fronded species of sect. Actinostachys, but in the dichotomous Lophi. dium such flanges become fused laterally into a 
flat and continuous surface. This interpretation brings the Schizaea leaf into accord with ordinary fern leaves, and also suggests a course of evolution. Prototypic schizaeas presumably had leaves like Mohria, pinnate in structure, the petiole shorter than the blade, and the sporangia borne on unmodified laminae. From such leaves, by reduction of blade and exaggeration of petiole, the basic Schizaea could evolve to the modern condition wherein blades are entirely eliminated in sterile and juvenile leaves, returning only at the sporeproduction stage of the life cycle. To my knowledge no true fern bears sporangia on petioles or midribs; the sporangia are borne always on the laminae lateral to the midrib, or their modifications, and it is unlikely that Schizaea is an exception.

Schizaea apparently not only lacks a normal leafblade except at time of spore-production, but it with little doubt has more derived features than any of the other Schizaeaceae; its spores are elliptic rather than tetrahedral, its gametophytes are filamentous rather than cordate, many of the species are epiphytes rather than terrestrial, and the sporangia are dorsiventral with a refined apical annulus, rather than radial with a crude patch of thickened cells as in Mohria. With so many modifications it is not inconsistent to have within the genus such secondarily modified petioles as those of the Bifidae and Lophidium.

Discussion.-Dichotomy of the major vascular axes of leaves in living ferns exists in four readily distinguished forms (excluding that of the Gleicheniaceae). Three of the types of foliar dichotomy involve the vascular architecture of the true leaf blade only. More or less horizontal orientation of the blades and dichotomous patterns of major vas. cularization affecting the entire blades characterize the midribless-blade type and the displaced-midrib type. In the former, the vascular axes are symmetrically forked and the morphological blade midrib is absent; mature leaves of this type are like the juvenile leaves of the same species. In contrast the displaced-midrib type possesses a blade midrib but it is modified and re-oriented; adult leaves of this type (known only in certain adiantums) are unlike the late juvenile leaves, which differ from mature ones in being pinnate in plan like ordinary fern leaves. In the crested-blade type, the blades are pendent in all except one case (the latter having pinnate-veined, non-dichotomous fertile leaves), and the dichotomous patterns affect only the upper portions of the blades, the furcation itself being noticeably irregular. Juvenile leaves of species showing the crested-blade form of dichotomy are unmodified, where these are known, and basically pinnate in plan. The forked-petiole type occurs only in certain schizaeas, and in these the dichotomy affects only the petiolar portion of the leaf, the morphological blades being pinnate in structure, although the latter are much contracted, and specialized wholly for reproduction. Among existing ferns in general, species with foliar dichotomy in the mature state are exceptional. Only the midribless type is common among juvenile leaves of ferns, and here it appears to be due to the failure of the normal blade apex to grow beyond the first pinna pair.

These examples of foliar dichotomy all seem to be modifications of pinnate leaves as evidenced by morphological and taxonomic comparisons, and they do not represent true primitive dichotomy in the morphological sense. Foliar dichotomy in living ferns appears to represent de novo dichotonty rather than retained psilophytalean dichotomy. In view of the far-reaching concepts of phylogeny that have been based on theories postulating the origin of pinnateness from dichotomy, it seems desirable that the nature of foliar dichotomy be further analyzed in its various forms, not only by taxonomic and morphological comparisons, but also by ontogenetic and morphogenetic studies as well.

\section{SUMMARY}

A survey of fern leaves with dichotomous major vascular axes was made in comparison with typical pinnately organized fern leaves. Four general types are distinguished: "midribless-blade type," with regular and symmetrical dichotomy of major veins, no midrib present, and mature fronds like the juvenile fronds; "displaced-midrib type," with regular but asymmetrical dichotomy, the midrib present but modified, and mature fronds unlike juvenile; "crested-blade type," with irregular dichotomy of the apex of the blade reflected in the vascular architecture, the blades pendent, and the juvenile fronds in known cases not forked; and "forked-petiole type," with apparently only the morphological petiole divided, the true blades pinnate, much contracted, and appearing only at the time of sporeproduction. The view is presented here that all the different types appear actually to be modifications of ancestral pinnately-organized leaves. The nature of different kinds of foliar dichotomy in vascular plants merits further analysis.

\footnotetext{
Department of Botany,

UNIVERSITY OF Michigan,

AnN Arbor, Michigan
}

\section{LITERA'TURE CITED}

Bower, F. O. 1923-28. The ferns (Filicales). I. (1923) Analytical examination and critical comparison. II. (1926) The eusporangiate and other primitive ferns. III. (1928) The leptosporangiate ferns. Cambridge University Press Cambridge.
Campbell, D. H. 1940. The evolution of land plants. Stanford University Press. Stanford University, California. Chrysler, M. A. 1941. The structure and development of Ophioglossum palmatum. Bull. Torrey Bot. Club 68: 1-19. 
Copeland, E. B. 1933. Trichomanes. Philippine Jour. Sci. 5l: $119-280$.

1947. Genera filicum. Chronica Botanica Company. Waltham, Massachusetts.

Eames, A. J. 1936. Morphology of vascular plants. Mc. Graw-Hill Book Company. New York.

Gleason, H. A., and E. P. Killip. 1939. The flora of Mount Anyan-Tepui, Venezuela. Brittonia 3: 141-204.

Goebel, K. 1929. Archegoniatenstudien XVIII. Roraema. farne. Flora 124: 3-21.

Holttum, R. E. 1949. The classification of ferns. Biol. Rev. 24: 267-296.

Hooker, W. J., and R. K. Grevill.t. 1828. Icones filicum. London.

LAM, H. J. 1948. Classification and the new morphology. Acta Biotheoretica 8: 107-154.

Lowe, E. J. 1867. Our native ferns. London.

Ogura, Y. 1938. Anatomie der Vegetationsorgane der Pteridophyten. In Linsbauer, Handbuch der Pflanzenanato. mie. Berlin.

ORTh, R. 1938. Zur Morphologie des Primärblätter einheimischer Farne. Flora 133: 1-5.5.
Posthumus, o. 1926. Notes on Guiana ferns. Recueil Trav. Bot. Neerland. 23: 396-402.

- 1929. Einige Eigentümlich der Blattform bei Dipteris und bei andern noch lebenden oder fossilen Pflan. zen. Recueil Trav. Bot. Neerland. 25: 251-291.

Schoute, J. C. 1936. On whorled phyllotaxis. III. True and false whorls. Recueil Trav. Bot. Neerland. 33: 670-685.

Strling, O. H. 1944. Studies in the recent and fossil species of Schizaea, with particular reference to their spore characters. Meddel. Göteborgs Bot. Trädgard. 16: 1-112.

Slosson, MaRy, 1906. How ferns grow. Henry Holt \& Co. New York.

Troll, W. 1938. Verglejchende Morphologie der höheren Pflanzen. I. Vegetationsorgane. Part II. Morphologie des Blattes. Gebruder Borntraeger. Berlin.

'Tryon, R. M. Jr. 1938. Forking in ferns. Amer. Fern. Jour. 28: 81.90 .

Vraboorn, F. (Ed.). 1938. Manual of pteridology. Martinus Nijhoff. The Hague.

Williams, S. 1927. A critical examination of the Vittariae with a view toward their systematic comparison. Trans. Roy. Soc. Edinburgh 55: 173-215.

\title{
THE EFFECT OF OXYGEN ON THE INDUCTION OF CHROMATID ABERRATIONS IN TRADESCANTIA MICROSPORES BY X-IRRADIATION ${ }^{1}$
}

\author{
Herbert Parkes Riley, Norman H. Giles, Jr., and Alvin V. Beatty ${ }^{2}$
}

DURING THE PAST few years numerous studies have shown that oxygen can affect the sensitivity of various organisms to ionizing radiation. Several of these studies have dealt with effects on chromosomes. Thoday and Read (1947) found that the per cent of anaphases with bridges or fragments in cells of the root tip of Vicia faba was much higher when the roots were X-rayed in the presence of oxygen than in its absence. Thoday and Read (1949) also found that the aberration frequency from alpha radiation was somewhat higher when oxygen was present, but that the increase is far less than it was with X-rays. Hayden and Smith (1949) similarly found that the frequency of late anaphase or early telophase figures with bridges was considerably higher when the root tips were X-rayed in air than it was when they were irradiated while in a vacuum.

Giles and Riley $(1949,1950)$ found that chromosome interchanges (dicentrics and centric rings) and interstitial deletions in microspores of Trades. cantia paludosa, as observed in metaphase and anaphase 4-5 days after irradiation, were less frequent when the air surrounding the buds was replaced with nitrogen, helium, or argon at the time of irradiation, or was removed so that the buds were

1 Received for publication Februarv 27, 1952.

Work performed under Contract No. W-7405-eng.26 for the Atomic Energy Commission.

2 Present addresses are respectively the University of Kentucky, Yale University, and Emory University. irradiated while in a vacuum. However, when the air was replaced with oxygen at the time of irradiation, the aberration frequency was higher than in air and much higher than in the absence of oxygen. That oxygen is the important factor was further demonstrated by placing the buds in varying per. centages of oxygen at the time of irradiation. Curves of Giles and Riley (1950) and Giles and Beatty (1950) show that the increase in aberration frequency is linear up to 10 per cent, and reaches an approximate plateau at about 21 per cent, after which the rise is quite gradual. Similar results have been obtained for reciprocal translocations detected genetically in Drosophila virilis (Baker, in Hollaender et al., 1952).

Two processes are involved in the production of chromosome aberrations. One is the initial breakage of the chromosomes; the other is the behavior of the chromosome ends after breakage occurs. The broken ends may rejoin in the preirradiation arrangement (restitution) removing the evidence that a break has occurred, or they may join in a new arrangement (reunion), or fail to rejoin at all and thus produce detectable aberrations. It seemed possible that oxygen might effect an increase in X-ray. induced aberration frequencies in either of two ways; i.e., by increasing the frequency of initial breakage or by influencing the recovery mechanism, such that reunion -was favored over restitution. Consequently, experiments were performed in which oxygen was introduced into the exposure chamber 